\title{
Erratum to: Livelihood Adaptation and Climate Variability in Africa
}

Lindsay Stringer, Claire Quinn, Rachel Berman, and Jami Dixon

\section{Erratum to:}

(C) The Editor(s) (if applicable) and The Author(s) 2016

J. Grugel, D. Hammett (eds.), The Palgrave Handbook of International Development, DOI 10.1057/978-1-137-42724-3_38

The name of the author was inadvertently published for chapter 38 . The correct name should read as Lindsay Stringer.

The updated original online version for this chapter can be found at DOI 10.1057/978-1-137-42724-3_38

L. Stringer

School of Earth and Environment, University of Leeds, UK

C. Quinn

Sustainability Research Institute, University of Leeds, UK

R. Berman

School of GeoSciences, University of Edinburgh, UK

J. Dixon

LTS International, UK

(C) The Editor(s) (if applicable) and The Author(s) 2016 